\title{
THE IMPORTANCE OF PHOTOGRAPHY AS AN INFORMATION SUPPORT IN EVENT MANAGEMENT (CASE EVENT OF ANUGERAH BAMBU INDONESIA 2013)
}

\author{
Anwar Basalamah; Maria Pia Adiati \\ Hotel Management Department, Faculty of Economic and Communication, BINUS University \\ Jln. K. H. Syahdan No. 9, Palmerah, Jakarta Barat 11480 \\ basalamah.a@gmail.com; mia_pia_adiati@hotmail.com
}

\begin{abstract}
This study aims to investigate the potential of media photography as a means of support in an event practice, analyze photography as data source in identifying the event practice, explore photography as documentation that helps in event execution, examine photography as visual language that supports the event management. From the case of an event organized by Anugerah Bambu Indonesia 2013, results from the study finds that photography has an added value as a data source, documentation, and visual language. This study proves that the theory EMBOK by Silvers, who categorizes photography as information management for event management, a theory which can be accounted for.
\end{abstract}

Keywords: photography, information support, event management

\begin{abstract}
ABSTRAK
Penelitian ini bertujuan untuk menyelidiki potensi media fotografi sebagai sarana pendukung dalam penyelenggaraan acara, menganalisis fotografi sebagai sumber data dalam mengidentifikasi penyelenggaraan acara, mengeksplorasi fotografi sebagai dokumentasi yang membantu dalam pelaksanaan acara, memeriksa fotografi sebagai bahasa visual yang mendukung manajemen acara. Dari kasus acara yang diselenggarakan oleh Anugerah Bambu Indonesia 2013, hasil dari studi ini menemukan fotografi yang memiliki nilai tambah sebagai sumber data, dokumentasi, dan bahasa visual. Studi ini membuktikan bahwa teori EMBOK yang dikemukakan oleh Silvers, yang mengategorikan fotografi sebagai manajemen informasi untuk manajemen acara, merupakan sebuah teori yang dapat dipertanggungjawabkan.
\end{abstract}

Kata kunci: fotografi, dukungan informasi, manajemen acara 


\section{INTRODUCTION}

Events have been around forever. The growth within the event industry shows that people have been successful in consistently creating bigger and better events. Today, the concept of events includes a large variety of social/life-cycle events, education and career events, sports events, entertainment events, political events, corporate events and religious events (Goldbaltt, 2000). It has become a fashion to use the word 'event' for everything that is happening.

With the current trends and the challenges arising in the event industry there is a high demand for creative managers who add value to the events while matching the clients' ideas with those of the organization's (Bilton \& Laery, 2002). With the globalization and the ease of travel nowadays, combined with the developments in technology, it is becoming more important to continuously educate students and event managers.

Technology is the single most important issue when creating an event. Modern technologies allow us to communicate with people around the world, get information and do the research necessary to evaluate the chances of an event. Information sources are essential for event visitors to find out about an event - they contribute to the success of an event, and organisers need to ensure they develop an effective and efficient information strategy to attract their target audience (Shanka \& Taylor in Smith, 2008).

Information is the first stage of distribution (Buhalis in Smith, 2008), the linking of supplier and consumer. Information attracts visitors (Hall, O’Sullivan, \& O’Sullivan in Smith, 2008), making them aware of the product, motivating the visit, and giving them the basis on which to make a decision over attendance. Smith (2008:2) states:

"There are multiple channels available for the distribution of event information, including brochures and flyers, broadcast and print media, the Internet, travel companies, and word of mouth. Given the competition within the event sector, it is important to understand the information sources used by event attendees, factor which influence an event organiser's decisions over which information channels to use, and whether through media electronic, printing, photography and so on."

In event industry, photography can be used in a broad variety of contexts, including recording participant, as data source, documentation and as visual language (Basil, 2011). The meaning of a photography is:

"...like that of any other entity, in inevitably subject to cultural definition. The task here is to define and engage critically something we might call the 'photographic iscourse'. A discourse is defined as an arena of exchange, that is, a system of relations between parties engaged in communicative activity." (Sekula, 1982:84)

The development of photography has followed the rapid technological process in every sector.

"Currently, digital photography plays an important role in the development of the photographic industry, along with the global warming issue. This digital technique has been indirectly supporting the philosophy of green, with a reduction for photo printing." (Sekula, 1982:88)

Photography is a crucial element in the organization of an event, particularly as documentation. Joseph (2006:8) states the value of documentation in the event industry through the following statement: 


\begin{abstract}
"Documenting an event can be useful for several aspects: recording experiences that capture the atmosphere and reflect the experiences of the event; reusing when organizing the next event; presenting to funding bodies of sponsors who have assisted the event; presenting to possible future funding bodies or sponsors, or interested parties evaluation and consideration of the good and bad points of the event."
\end{abstract}

Additionally, Silvers (2007:9) through her The Event Management Body of Knowledge or EMBOK model has categorized photography in the domain of information management, along with a number of elements such as briefings or debriefing, distribution of information, communication planning, and so on. In MICE industry there is also a term known as 'special event', which is described by Macnamara (1996:154) as:

\begin{abstract}
"Special event is an event that is usually held to get the media attention that led to public concern about the company (or organization) or the company's products. Designing a specific event, or better known special event, is selected in term time, place, and specific nature of specific objects to influence public opinion."

Shone and Parry (2004:3) define 'special event' as follow:

"Special events are that phenomenon arising from those non-routine occasions which have leisure, cultural, personal or organizational objectives set apart from the normal activity of daily life, whose purpose is to enlighten, celebrate, entertain or challenge the experience of a group of people."
\end{abstract}

So special event is an event that is usually held to get the media attention that led to public concern about the company (or organization) or the company's products. Designing a particular event or better known as special events (special event) is selected in terms of time, place, and specific nature of specific objects to influence public opinion. According to Fenich (2012:141) "Special event: One time event staged for the purpose of celebration; unique activity". Torkildson (1986:456) says:

\begin{abstract}
"Events are an important part of any comprehensive community recreation programme. They capture the imagination. Events can involve the community; they can increase awareness; they can help put an organization or an activity on the map.Event can bring top class performers, entertainment, novelty, adventure, surprise and fun to add height, width, depth and glamour to a programme."
\end{abstract}

This also applies in Indonesia where many festivals have been held in all its regions. One of them has become an annual festival held by the Ministry of Tourism and Creative Economy such as Bambu Nusantara Festival featuring music artists and works of bamboo-based music. Festival Musik Bambu was held at the Jakarta Convention Center (JCC) in September 2013. The event brings a variety of creations made from bamboo and an appearance of diverse arts of bamboo. Besides ethnic music combined with modern music, the event will also be co-filled with exhibitions, seminars, merchandise, culinary, and fashion are combined with works made from bamboo.

The event will also be celebrating musicians in the country that carry both ethnic and modern music. It will show how the bamboo musical instrument in the hands of talented musicians collaborated with contemporary music such as jazz, rap, rock, and disc jockey. The festival will also be a musical feast where modern musical instrument angklung collaborate with exotic sounds, karinding, celembung, flute, calung, lodong, and various other bamboo musical instruments (Indonesia Travel, 2012:1).

Previously there was also Indonesian Bamboo Music Festival held at the Pasteur Hyper Point, Jl. Dr. Djundjunan No. 126-128 Bandung on Saturday, 16 February 2013. The festival aimed to raise bamboo-based traditional art. It was based on a situation where lack of respect for traditional artists will lead to an a point where traditional art die slowly, "One of the problems of traditional art is 
increasingly reduced public appreciation of traditional art, the artists we often practiced but rarely performed because of the facilities and infrastructure are still lacking." (Pemkot Bandung, 2012:1)

Indonesia has an assortment of bamboo-based culture that is unique and special. Bamboo is a kind of plant that has deep roots in cultures in various regions in Indonesia. Even bamboo cannot be separated from the life of Indonesian history. According to Ilyas Assaad, Deputy Minister of Environment Affairs and Communications Environment Community empowerment (Sindo News 2012:1),

"The U.S. market alone could be up to \$ 20 million bamboo. Meanwhile 68 per cent controlled by China. But, we also do not actually lose. 1,500 species of bamboo in the world, Indonesia has 150 species. Many as 88 species of which 55 species are native Indonesia and that has value economical."

The technological development is currently very influential in progress in the field of photography. MICE event organizers or perpetrators are challenged to keep up with the times by harnessing photography not only as a form of marketing activity supporting our other features. Function and use of photography in the MICE industry still needs to be explored in the development and progress of the event industry itself. This paper will touch above notions by literature reviews to explore and identify the importance of photography as an information management in an event execution of Anugerah Bambu Indonesia 2013 that has been held on May 25, 2013 at EcoArt Park, Sentul City, Bogor.

\title{
RESEARCH METHOD
}

Ethnography is advocated as an appropriate research approach to the events field (Holloway, 2010:74). This statement is reinforced by further research accomplished by several researchers as described in the following statements.

\begin{abstract}
"Ethnography is a research approach that is utilised extensively within the social science disciplines of anthropology and sociology (Roberts and Sanders, 2005) and has also begun to inform the applied fields of management (Schultze, 2000; Carlile, 2002; VanMaanen, 2011), education (Vaughan, 2004; Tsolidis, 2008), tourism (O'Gorman et al., 2012), as well as sport, event and leisure studies (Cohen, 1993; Sparkes, 2009; Noy, 2011; Fullagar and Pavlidis, 2012). The value of the ethnographic approach is that it is uniquely placed to access the cultural world of research participants, in this case festival organisers and producers." (Stadler, Reid, and Fullagar, 2013: 91-92)
\end{abstract}

Moreover Stadler, Reid, and Fullagar (2013:92) states:

"Ethnographic research prioritises the perspectives of those being studied, which is achieved through researchers experiencing and engaging within the participants'setting. The researcher spends an extended period of time with participants, observes and participates in day-to-day practices and key events and becomes fully immersed in the culture of the organization (Kellehear, 1993; Brewer, 2000; Humphreys et al., 2003; Sjoestedt Landen, 2011). Observation can be conducted in an overt or covert manner, meaning that either all participants know about the researcher's presence or the researcher's identity is concealed. Either way, the challenge for the participant observer is to maintain a balance between their "insider" and "outsider" perspective."

The method is used to examine how the variables of photography are implemented into the event management of Anugerah Bambu Indonesia 2013. 


\section{RESULTS AND DISCUSSION}

\section{Event Management}

Getz (2000:4) defines events as "temporary occurrences, either planned or unplanned". To describe the difference between unplanned and planned events, the word event is preceded by the word 'special', to indicate a human element; therefore a special event is a "one-time or infrequently occurring event outside a normal program" (Getz, 2000:4). Due to the human element of planning and managing, events have been growing rapidly and have become bigger and bigger.

People have gathered to attend meetings, conventions and expositions since many years ago, mainly for social, sporting, political or religious purposes (Walker, 2009:8). A proper management seems to be a crucial aspect for successful events. According to Getz (2007:404):

"Event management is the applied field of study and area of professional practice devoted to the design, production, and management of planned events, encompassing festivals and other celebrations, entertainment, recreation, political and state, scientific, sport and arts events, those in the domain of business and corporate affairs (including meetings, conventions, fairs, and exhibitions), and those in the private domain (including rites of passage such as weddings and parties, and social events for family groups)."

He also states that:

"Anyone studying event management, often within a business-school environment, also has to learn something about design and production, and must understand some fundamental knowledge and theories about events that are of necessity derived from other disciplines and professional fields.” (Getz, 2007:439)

Other perspectives came from McCartney (2010:6):

"Event management is a multidisciplinary phenomenon involving marketing, catering, finance, security, and risk management, logistics and human resource management, among other disciplines. However, as the event management is commonly focusing on the activities planned by the social or economic purpose, event study has a broader scope a bit of attention."

Walker (2009:8) suggests:

"Event management requires special skills in marketing and sales, planning, organization, financial, human resources and motivation, and also lots of patience and attention to details and endless checking upon on them."

The body knowledge associated with event management has growth. Julia Silvers has come up with the "Event Management Body of Knowledge" or commonly called EMBOK believes:

"Event management is the process by which an event is planned, prepared, and produced. As with other form of management, it encompasses the assessment, definition, acquisition, direction, control and analysis of time, finances, people, products, services and other resources to achieve objectives." (Getz, 2007)

The EMBOK Structure Model provides a three dimensional approach to event management.

"The sequential aspect of the phases and iterative nature of the processes, which are permeated with core values, allows one to approach the functional areas in a comprehensive and systematic manner. The knowledge domains that include the functional areas, referred to 
as classes in the model, provide a logical taxonomy illustrating the scope of event management. This taxonomy facilitates categorizing these functions into modules or fields of study, defining areas of responsibility." (Silvers, 2005: 5)

Moreover, Silvers (2005:5) says:

"Professional knowledge, which consists of technical knowledge, specialized skills, and ethical standards used to function within a professional jurisdiction, must be transformed into formal knowledge systems combined with experiential or situational knowledge systems."

The proposed knowledge domain structure: "captures and makes explicit the scope of this knowledge system, and provides a taxonomy for incorporating additional expertise, experience, and transferred knowledge and applications” (Silvers, 2005:6). It is as illustrated in Table 1 as follows.

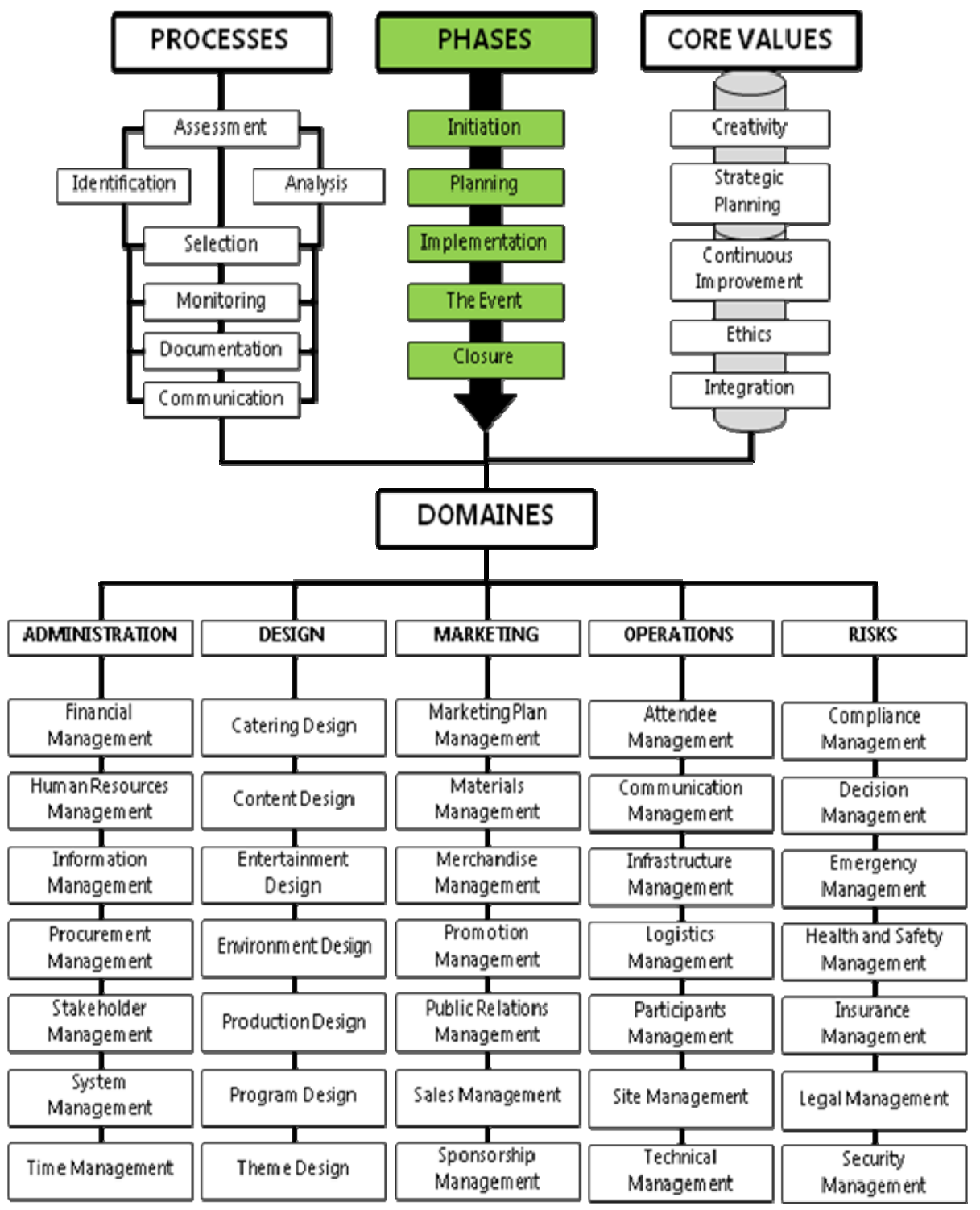

Figure 1 Facets of the EMBOK Source: Silvers (2005) 
This paper discusses one part of the administration domain, which is called information management.

"The Administration domain deals primarily with the proper allocation, direction and control of the resources used in an event project. Because resources are finite by definition, it is imperative that they be acquired, developed and utilized in the most efficient and effective manner to benefit the event project and limit its risk." (Silvers, 2005:8)

Silvers (2005:8) states that information management as: the acquisition, distribution, control and retention of information through the implementation of customary reporting, record keeping, and protection procedures for privacy and proprietary information to ensure the necessary business intelligence and institutional memory is captured and preserved. She also describes several aspects that involved in the information management, which are:

\begin{abstract}
"Briefings/Debriefings, Communication, Equipment, Communication Planning, Communication, Protocols, Confidentiality, Agreements, Database Management, Documentation, Procedures, Document Design, Evaluation/Analysis, Feedback Systems, Information Acquisition, Information Asset, Protection, Information Distribution, Intelligence Gathering, Lead Retrieval Systems, Library/Archives, Monitoring and Reporting, Presentations, Photography/Videography, Privacy Policies, Record Keeping, Procedures." (Silvers, 2005:8)
\end{abstract}

It is unquestionable that events have become a significant part of our lives, and there are several trends that lead to the supposition that the event industry, if managed correctly, has prospects of further expansion. Goldblatt (2000:8) estimates:

"...with the growing age of the world's population there will be a significant increase in celebrations. The requirements for all events will increase with the innovation of technology and the desire for 'high-touch experiences'. His predictions from 2000 for the year 2010 have become partly truth and therefore his predictions for the years to follow are worth serious consideration."

\title{
Photography
}

Photography is defined as the art or practice of taking and processing photographs (Datta, Joshi, Li \& Wang, 2006:1). It also means as "technology for capturing and producing a static image of an object/person/environment, providing evidence of particular significant features relates to the research project issues” (Gray and Malins, 2004:7). As Basil (2011:254) says:

"Whether applied to looking into a different culture or time, or illustrating common activities that we may miss, as the saying goes 'a picture is worth a thousand words'. Sometimes, a picture or video may be the best or only way to explain a situation to others.”

Sassoon (2007:301) describes the meaning of photography in relation to the technology manner. She believes:

"A photograph is the product of the confluence of the technology, the photographer's eye and the printer's hand; processes which have been described as containing the aura of the alchemy."

Accordingly, photographs have been utilized for various purposes from a long time ago. There are a number of fields, including business, anthropology and sociology, which have embraced the used of photography for research purposes (referring to Table 1). 
Table 1 Use of Photography for Research

\begin{tabular}{lll}
\hline \multicolumn{1}{c}{ Discipline } & \multicolumn{1}{c}{ Purposes } & \multicolumn{1}{c}{ Source \& Year } \\
\hline Anthropology & $\begin{array}{l}\text { Anthropology used photography to record and } \\
\text { demonstrate exotic cultures }\end{array}$ & $\begin{array}{l}\text { Collier and Collier, 1986 } \\
\text { (Basil, 2011) }\end{array}$ \\
\hline Sociology & $\begin{array}{l}\text { Sociologists have proved that visual images are } \\
\text { an important part of their research, so much that } \\
\text { their field may even be identified as 'visual } \\
\text { sociology' }\end{array}$ & Harper, 1998 (Basil, 2011) \\
\hline & $\begin{array}{l}\text { Photography used time-lapse and motion- } \\
\text { triggered photography to study animals in the } \\
\text { wild. }\end{array}$ & $\begin{array}{l}\text { Cutler and Swan, 1999 } \\
\text { (Basil, 2011) }\end{array}$ \\
\hline & $\begin{array}{l}\text { Photography used to examine how people } \\
\text { understand and interpret their world. }\end{array}$ & Crang, 1997 (Basil, 2011) \\
\hline Medicine \& Nursing & $\begin{array}{l}\text { Photography found as a form of documentation } \\
\text { that 'assume the status of evidence' and can be } \\
\text { employed to 'faithfully capture what really goes } \\
\text { on'. }\end{array}$ & $\begin{array}{l}\text { Riley \& Manias, 2004 } \\
\text { (Basil, 2011) }\end{array}$ \\
\hline
\end{tabular}

In the convention industry, the photography has been used "to record events and their timing as well as selection and the displays” (Heisley et al. in Basil, 2011:250). Moreover, Heisley et al (Basil, 2011:250) state:

"Genuine photographs can have remarkable effects on what we remember and believe. Photographs help people illustrate the stories of their lives and the significant stories of their society. However, photographs can do more than illustrate events; in this article, we show that photographs can be used for some of roles."

\section{Photography as Data Source}

Photography has been exercised: “to examine the entire season of a farmers'market. The study used 1,377 photographs as part of a variety of data sources including participant observation, directive and nondirective interviews, development of key informants, journal entries, audio and audio/video recordings.” (Heisley et al in Basil, 2011:250). Photography has also been employed as a source of primary data. Wallendorf and Arnould in Basil (2007:253) state:

"In the field of marketing, Wallendorf and Arnould's study of Thanksgiving rituals made use of over 2,500 photographs to document archetypical events, their flow, participants and their proxemics, as well as the stability of these celebrations over time."

Similarly, Basil (2007:253) used photographs:

"to compare traditional farmers'markets in Canada and Italy. Despite some initial expectations about thesemarkets, analysis of the photographs revealed deeper insights into the differences between these two countries that required the sort of hindsight and immediate comparisons that could best be afforded through the use of photographs as a primary source of data."

Using pictures in social research requires a theory of how pictures get used by both picture makers and viewers. It is as Schwartz (1989:119) says:

"In order to use photographs either as data or as data generators we need to have some notion of how viewers treat and understand photographic images, whether those viewers are informants or researchers." 
Based on the results of photography that captured the event Anugerah Bambu Indonesia 2013, the indicators of photography as a data source can be described as follows:

\section{Document Archetypical Event}

The event can be categories as special event that offer series of positive program to community, environmentalist, students and public. It was attended by government representative Assistant Deputy Community Development of the Ministry of Environment and the Indonesia Bamboo Foundation as well as Indonesia Bamboo Community, which creates a prestige image to the public.

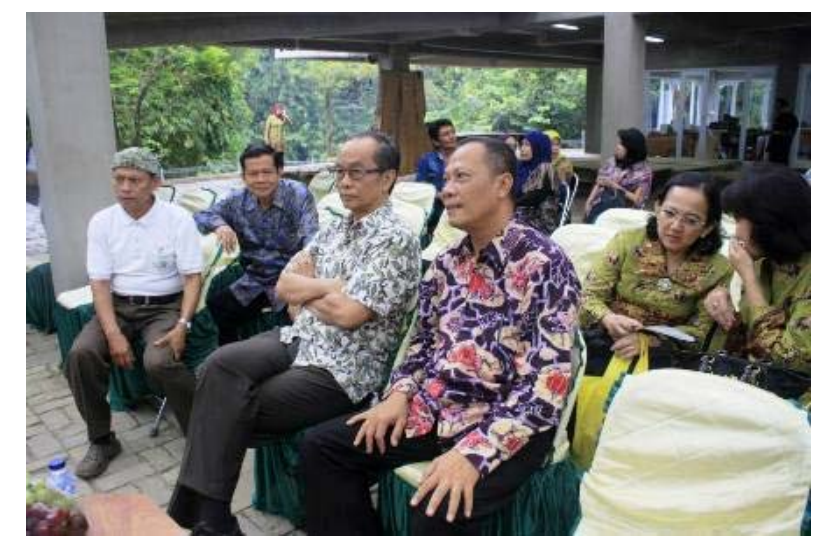

Figure 2 Assistant Deputy Community Development of the Ministry of Environment, Mr. Bambang Trilaksono and Former Minister of the Environment, Mr. Sarwono Kusumaatmadja

The event offers remarkable experience for community, environmentalist, government and public, as expanding their networking and help in increasing public awareness about bamboo in Indonesia. It can be proved that the photography tends to be an appropriate media as source of data. This media helps as supporting main source of data, especially in regard to proofing some kinds of situation/condition. For event industry, the photography still a favorite media and become a must medium in verify what happened in the event.

\section{Photography as Documentation}

Photographs are commonly used to document events because they are fairly inexpensive, easy to organize and provide a good result (Joseph, 2006). Basil (2011:247) says:

"The objective perspective believes that photography records reality 'written by light' so that image reflect an omniscient recording of reality as it occurred and the camera acts simply as mnemonic device that requires no special knowledge to interpret. This is seen in the term 'documentary photography'."

Wallendorf and Arnould (in Basil, 2011:249) also used photography "to examine Thanksgiving rituals. In this case, they had junior collaborators photograph their celebrations and arranged the photographs sequentially to document the temporary flow of the event”.

Other views of the photographic in research came from different field as Riley and Manias in Basil (2011:248):

"Riley and Manias has categorized the use of photography as documentation (and surveillance); therapeutic intervention; teaching; learning; and evaluating performance; 
research methods; and descriptive (instructional). They identified several common uses of photography including observational and photo elicitation, and others uses that have not achieved their full potential including self-portraits and video modelling."

In addition, Belk et al in Basil (2011:249) came up with an idea: "photos recorded information on the general site for the researchers, as a device that was shown to remind them of the situation and their behaviour, and as an external check (or 'audit') of the field data and conclusion."

According to the photo at the event of Anugerah Bambu Indonesia 2013, it can be found number aspects that suggest the importance of photography as documentation.

\section{Reminder of the Situation}

In some conditions, the photos in the event can be recorded as reminder of the situation around the event, such as:

\section{The Venue}

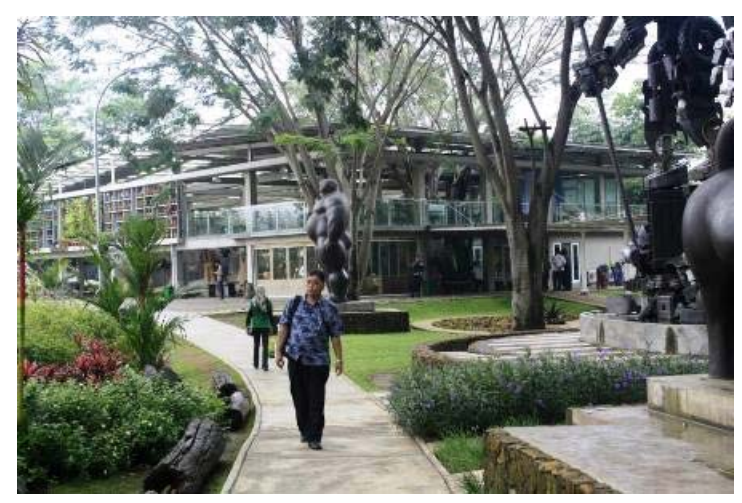

Figure 3 Eco Art Park, Green House, Sentul City, Bogor as the Venue of Anugerah Bambu Indonesia 2013

\section{The Special Moments}

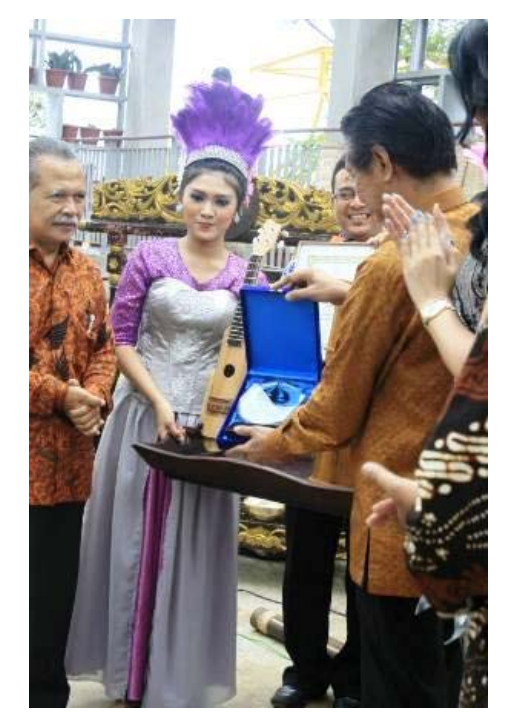

Figure 4 Tribute to Sentul City Management as the Host of Anugerah Bambu Indonesia, 2013 


\section{External Check/Audit}

All photos of the event can be used for the external audit, whether all vendors have been performed based on the request. For instance:

\section{Decoration}

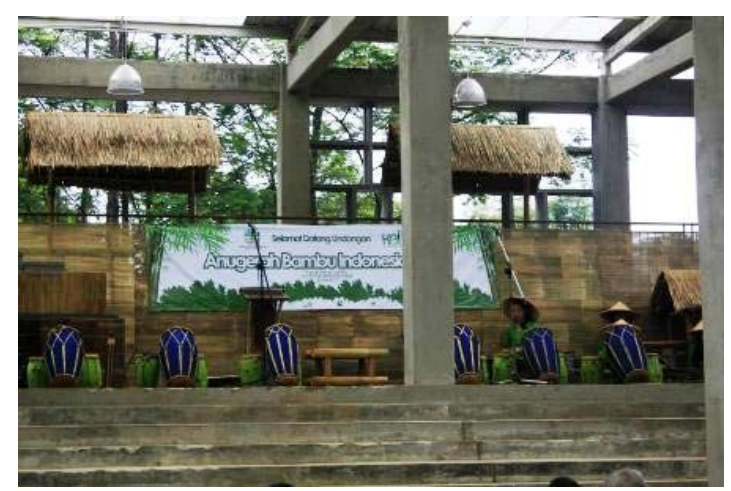

Figure 5 Natural Decoration of Anugerah Bambu Indonesia, 2013

\section{Entertainment}

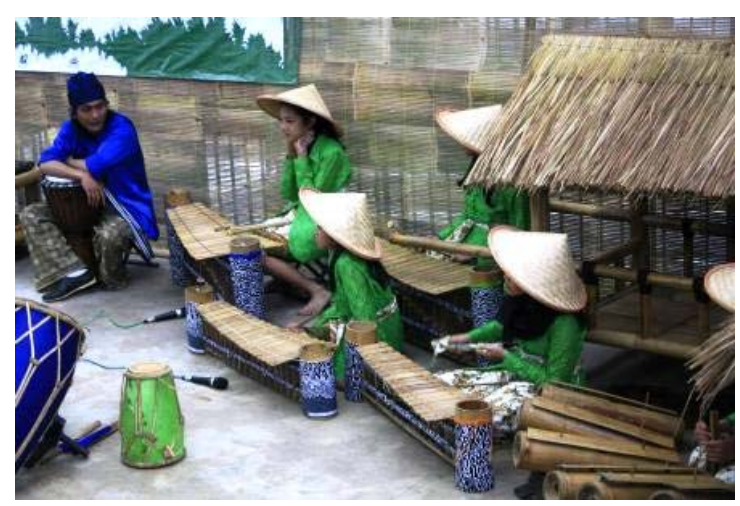

Figure 6 The Bamboo Music Orchestra in Anugerah Bambu Indonesia, 2013

\section{Photography as Visual Language}

The communicative and structural characteristics of photography can be compared to those of verbal language in that "photographs hold the same subjective, interpretive potential as words" (Moran and Tegano in Close, 2007:33). Moran and Tegano (in Close, 2007:33) suggest that: "if photography is a visual language, then it must (like verbal communication) include meanings (semantics), interpretation based on context (pragmatics), a sense of order (as in syntax or word order)." In addition to these language rules, Meyrowitz (in Close, 2007:34) categorises the choice of angle and distance from the scene being photographed as 'para-proxemics', which can be used as 'a means of affecting the viewer's emotions or attitudes' (Messaris in Close, 2007:34).

Photography in relation to its potential as a language to communicate things to us in relation to the order in which photos are placed (Banks in Close, 2007) and the distance from the image (Rose in Close, 2007). Moreover, Moran and Tegono (in Close 2007:33) say: 
"Photography has the potential to be a visual language with which we can chronicle and represent reality, a research method that can be used to generate knowledge and effect change, and provide a bridge between the two."

Hesford and Brueggmann (2006:110) state:

"Because photography literally means 'to write or draw with light', it seems natural that we are able to "read" photographs just like we read any other text. Visual literacy refers to the ability to "read" an image, much like the way we "read" language."

Moreover, they say: "This form of literacy requires an awareness of "visual rhetoric"-the ways that visual images communicate meaning. Visual rhetoric does not only include specific concepts of design or aesthetic theory.” (Hesford and Brueggemann, 2006:131)

Photography also describes how images reflect, communicate, and even shape cultural meaning (Hesford and Brueggemann, 2006). They (2006:119) believe "photographic analysis involves examining the image(s) in terms of subject/content, perspective, and audience/content, all part of a so called rhetorical triangle. The rhetorical triangle consists of: (1) Subject/Content: the subjects of the image, their appearance and gaze, the components of the image, their arrangement, the use of color, and where your eye is drawn within the image, the types of narrative elements present in the imagewhat story is told? Is there an implied chronology before or after the image? (2) Audience/Context: the historical and cultural contexts from which the image emerged, the historical and cultural contexts in which the image is seen or read-the contexts surrounding audience, the message/image itself, and how historical and cultural contexts shape the way a particular theme or subject is presented; (3) Perspective: the photographer's/filmmaker's gaze or perspective and camera angle, the framing of the subject matter, the use of the camera to establish an illusion of intimacy, or sense of distance. The rhetorical triangle is seen as Figure 7 follows.

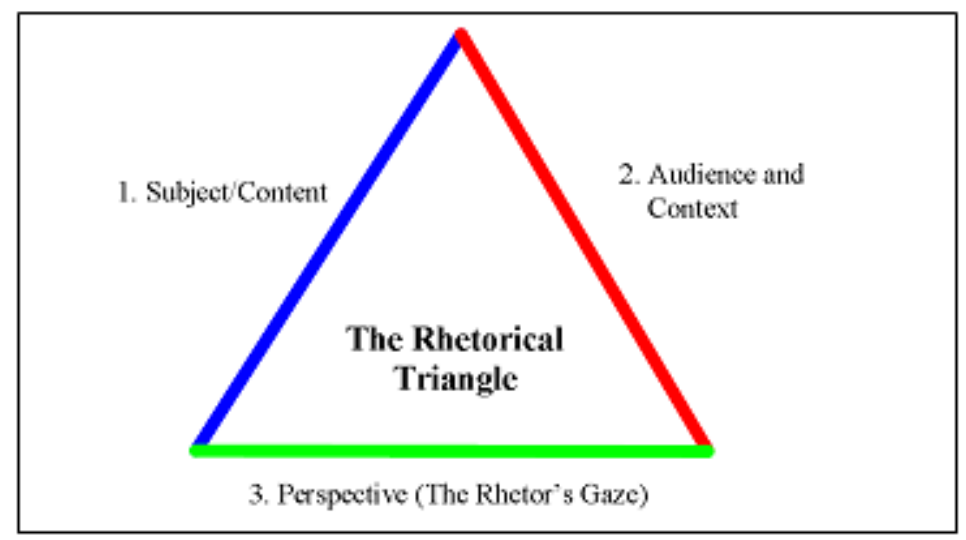

Figure 7 The Rhetorical Triangle

(Source: Hesford and Brueggemann, 2006)

The following photos have expressed the subject, audience and perspective of the event as the visual of language.

\section{Subject/Content}

The photography result in the event clearly showed several activities that may be seen in the event process. 


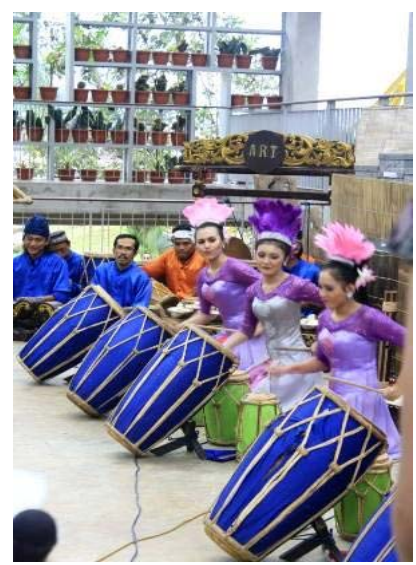

Figure 8 The traditional dancing of Sunda Culture: Rampak Gendang

\section{Audience/Context}

According to the below photos, they show the mix visitors who attend the event - community, governmental associates, education decision makers, students and so on.

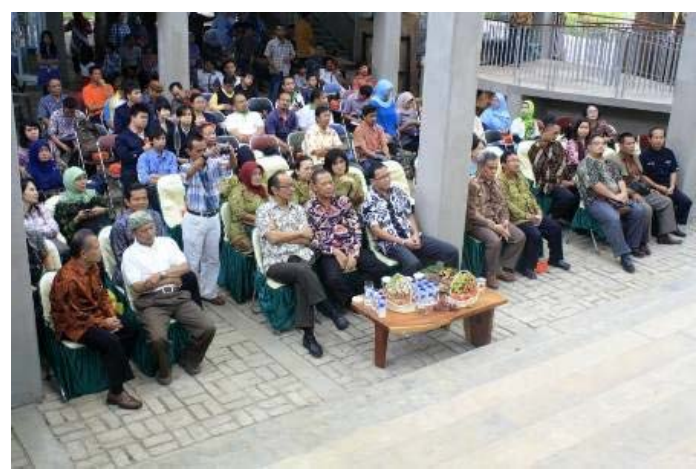

Figure 9 The Audience of Anugerah Bambu Indonesia, 2013

\section{CONCLUSION}

Based on the observation and documentation research in the event of Anugerah Bambu Indonesia 2013, this study established the fact that the photography media has perceived event practices in constructive way. It is important to note that both recognized that photography can help in showing the implementation of event practices. The result of photos on the event Anugerah Bambu Indonesia 2013 has verified the photography as an appropriate data source for event management. It also facilitates in documenting any moment in the event and tends to be a crucial part in the event documentation.

Additionally, photograph has the potential to be a visual language of the event with which we can chronicle and represent reality, a research method that can be used to generate knowledge and effect change, and provide a bridge between the two (Moran and Tegano in Close, 2007). Photography as a research method in this study was both communicative and generative - communicative because it provoked and conveyed meaning, and generative because through discussions and analysis of the photographs, new understandings and deeper insights were created. 
Moreover, photography as documentation tends to be a crucial aspect in the event management. Numerous photos facilitate in remind the accurate circumstances all through the event. Photography proved to be a powerful tool with which to alter the dynamics for the researchers in order to ensure that the research experience was meaningful. Finally, photograph generates visual language of the event in some vital factor the result of photo in the event was both communicative and generative. It has proved that aid in observing the subject image (talents, master of ceremony, etc). It also helps in recording the archetypical event, the flow of event, the audience.

In summary, the research results prove that the theory EMBOK by Silver, who categorized photography as information management for event management, can be accounted for.

\section{REFERENCES}

Basil, M. (2011). Use of Photography and Video in Observational Research. Qualitative Market Research: An International Journal. Vol.14, No. 3, 246-257.

Bilton, C. and Laery, R. (2002). What can managers do for creativity? Brokering creativity in the creative industries. International Journal of Cultural Policy. Vol. 8 (1), 49-64.

Close, H. (2007). The Use of Photography as Qualitative Research Tool. Nurse Researcher. Vol. 15, No. 1. United Kingdom.

Datta, R., Joshi, D., Li, J., and Wang, J. Z. (2006). Studying Aesthetics in Photographic Images Using a Computational Approach. USA: The Pennsylvania State University, University Park.

Getz, D. (2000). Defining the Field of Event Management. Event Management. Vol. 6 (1), 1-4.

Getz, D. (2007). Event Studies. Oxford: Elsevier.

Goldblatt, J. "A Future For Event Management: The Analysis Of Major Trends Impacting The Emerging Profession.” 2000. New Jersey: John Wiley and Sons.

Gray, C., Malins, J. (2004). Visualizing Research. A guide to the research in art and design. Farnham UK \& Burlington USA: Ashgate.

Harper, D. (1994). On the authority of the image. Visual methods at the crossroads. Denzin NK, Lincoln, YS (Eds) The Sage Handbook of Qualitative Research. 408-417. First Edition: London, Sage.

Hesford and Brueggemann. (2006). Rhetorical Visions: Reading and Writing in a Visual Culture. New Jersey: Upper Saddle River.

Joseph, J. A. (2006). Documentation. Participatory Adult Learning, Documentation and Information Networking (PALDIN), Group of Adult Education, School of Social Science, Jawaharlal Nehru University, New Delhi, India, pp. 8-12.

McCartney, G. (2010). Event Management. An Asian Perspective. Singapore: McGraw-Hill Education. 
Moran, M. J. and Tegano, D. W. (2010). Moving toward visual literacy: photography as a language of teacher inquiry. Early Childhood Research and Practice. Vol. 7, No. 1 1-20. Retrieved July 17, 2013 from http://ecrp.uiuc.edu/v7n1/moran.html.

myEtymology. (2008). Event. Myetymology.com - the etymology of all words. Retrieved from http://www.myetymology.com/english/event.html

Sassoon, J. (2007). Photographic Meaning in the Age of Digital Reproduction. Archives \& Social Studies: A Journal of Interdisciplinary Research. Vol. 1, No. 0 March, 2007.

Sekula, A. (1982). On the Invention of Photographic Meaning Thinking Photography ed. London: Palgrave Macmillan, 84-109.

Silvers, J. R. (2005). Global Knowledge Domain Structure for Event Management. Las Vegas.

. (2007). The Potential of the EMBOK as a Risk Management Framework for Events. Las Vegas.

Smith, K. A. The Information Mix for Events: A Comparison of Multiple Channel used by Event Organizers and Visitors. International Journal of Event Management Research. Vol. 4, No.1. Victoria University of Wellington, New Zealand.

Stadler, R., Reid, S., and Fullagar, S. (2013). An ethnographic exploration of knowledge practices within the Queensland Music Festival. International Journal of Event and Festival Management. Vol. 4, Iss. 2, pp.90 - 106. 